\title{
Use of acid-suppressive drugs and risk of pneumonia: a systematic review and meta-analysis
}

\author{
Chun-Sick Eom MD MPH, Christie Y. Jeon ScD, Ju-Won Lim MD, Eun-Geol Cho MD, Sang Min Park MD PhD, \\ Kang-Sook Lee MD PhD
}

Competing interests:

None declared.

This article has been peer reviewed.

Correspondence to: Dr. Sang Min Park, sangmin .park.snuh@gmail.com and Dr. Kang-Sook Lee, leekangs@catholic.ac.kr

CMAJ 2011. DOI:10.1503 /cmaj.092129

\begin{abstract}
Background: Observational studies and randomized controlled trials have yielded inconsistent findings about the association between the use of acid-suppressive drugs and the risk of pneumonia. We performed a systematic review and meta-analysis to summarize this association.
\end{abstract}

Methods: We searched three electronic databases (MEDLINE [PubMed], Embase and the Cochrane Library) from inception to Aug. 28, 2009. Two evaluators independently extracted data. Because of heterogeneity, we used random-effects meta-analysis to obtain pooled estimates of effect.

Results: We identified 31 studies: five casecontrol studies, three cohort studies and 23 randomized controlled trials. A meta-analysis of the eight observational studies showed that the overall risk of pneumonia was higher among people using proton pump inhibitors (adjusted odds ratio [OR] 1.27, 95\% confidence interval $[\mathrm{Cl}] 1.11-1.46, l^{2} 90.5 \%$ ) and

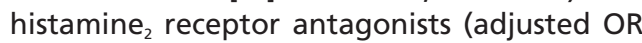
$\left.1.22,95 \% \mathrm{Cl} 1.09-1.36, I^{2} 0.0 \%\right)$. In the randomized controlled trials, use of histamine receptor antagonists was associated with an elevated risk of hospital-acquired pneumonia (relative risk 1.22, 95\% Cl 1.01-1.48, 2 30.6\%).

Interpretation: Use of a proton pump inhibitor or histamine ${ }_{2}$ receptor antagonist may be associated with an increased risk of both community- and hospital-acquired pneumonia. Given these potential adverse effects, clinicians should use caution in prescribing acid-suppressive drugs for patients at risk.
$\mathrm{R}$ ecently, the medical literature has paid considerable attention to unrecognized adverse effects of commonly used medications and their potential public health impact. ${ }^{1}$ One group of medications in widespread use is acid-suppressive drugs, which represent the second leading category of medication worldwide, with sales totalling US $\$ 26.9$ billion in 2005 . $^{2}$

Over the past 40 years, the development of potent acid-suppressive drugs, including proton pump inhibitors, has led to considerable improvements in the treatment of acid-related disorders of the upper gastrointestinal tract. ${ }^{3}$ Experts have generally viewed proton pump inhibitors as safe. ${ }^{4}$ However, potential complications such as gastro intestinal neoplasia, malabsorption of nutrients and increased susceptibility to infection have caused concern.

Of special interest is the possibility that acidsuppressive drugs could increase susceptibility to respiratory infections because these drugs increase gastric $\mathrm{pH}$, thus allowing bacterial colonization. ${ }^{67}$ Several previous studies have shown that treatment with acid-suppressive drugs might be associ- ated with an increased risk of respiratory tract infections $s^{8}$ and community-acquired pneumonia in adults ${ }^{6.7}$ and children. ${ }^{9}$ However, the association between use of acid-suppressive drugs and risk of pneumonia has been inconsistent. ${ }^{10-13}$

Given the widespread use of proton pump inhibitors and histamine ${ }_{2}$ receptor antagonists, clarifying the potential impact of acid-suppressive therapy on the risk of pneumonia is of great importance to public health. ${ }^{14}$ Previous metaanalyses have focused on the role of acidsuppressive drugs in preventing stress ulcer, ${ }^{11,13,15}$ but none have examined pneumonia as the primary outcome.

The aim of this study was to summarize the association between the use of acid-suppressive drugs and the risk of pneumonia in observational studies and randomized controlled trials.

\section{Methods}

The procedures used for this meta-analysis were consistent with recent guidelines for reporting of meta-analyses. Specifically, we followed the 
Meta-analysis Of Observational Studies in Epidemiology (MOOSE) guidelines ${ }^{16}$ for observational studies and the Preferred Reporting Items for Systematic reviews and Meta-Analyses (PRISMA) statement ${ }^{17}$ for randomized controlled trials.

\section{Search strategy and data sources}

We searched for studies that reported an estimate of effect for a potential association between the use of acid-suppressive drugs and the risk of pneumonia. We included observational studies and randomized controlled trials that were published as original articles.

We searched MEDLINE (PubMed), Embase and the Cochrane Central Register of Controlled Trials (CENTRAL) in the Cochrane Library from inception to Aug. 28, 2009. We also searched the bibliographies of relevant articles to identify additional studies.

To identify observational studies, we used the following combinations of search terms: ("acidsuppressive therapy" OR "acid-suppressive drugs" OR "acid-suppressive medications" OR "gastric acid suppressants" OR "proton pump inhibitors" OR "proton pumps" OR omeprazole OR nexium OR lansoprazole OR rabeprazole OR pantoprazole OR esomeprazole OR " $\mathrm{H}_{2}$ receptor antagonists" OR "histamine2 receptor antagonists" OR cimetidine OR ranitidine OR famotidine OR nizatidine) AND (pneumonia OR "community-acquired pneumonia" OR "nosocomial pneumonia" OR "hospital-acquired pneumonia" OR "intensive care unit"). We restricted this search to studies involving humans that were published in English.

To identify randomized controlled trials, we used the following combinations of search terms: ("acid-suppressive therapy" OR "acid-suppressive drugs" OR "acid-suppressive medications" OR "gastric acid suppressants" OR "proton pump inhibitors" OR "proton pumps" OR omeprazole OR nexium OR lansoprazole OR rabeprazole OR pantoprazole OR esomeprazole $\mathrm{OR}$ " $\mathrm{H}_{2}$ receptor antagonists" OR "histamine 2 receptor antagonists" OR cimetidine OR ranitidine OR famotidine OR nizatidine). We restricted this search to randomized controlled trials.

\section{Study selection}

We included any study that met all of the following criteria: was a case-control study, cohort study or randomized controlled trial; investigated the association between use of acid-suppressive drugs and risk of pneumonia; quantified the outcome with adjusted odds ratios (ORs), relative risk or number of events, and corresponding 95\% confidence intervals (CIs); and reported the results for proton pump inhibitors and histamine ${ }_{2}$ receptor antagonists separately. For studies that provided stratum-specific estimates, we combined them by means of the inverse-variance method. We included randomized controlled trials comparing acid-suppressive drugs (intervention) with either placebo or sucralfate control, as we were interested only in the influence of acid suppression on pneumonia.

\section{Data extraction and quality assessment}

Two investigators (C.S.E., J.W.L.) independently evaluated the eligibility of all studies retrieved from the databases on the basis of the predetermined selection criteria. They resolved any disagreements by discussion or in consultation with the co-corresponding authors (S.M.P., K.S.L.).

We assessed the methodologic quality of observational studies with the Newcastle-Ottawa Scale ${ }^{18}$ and that of randomized controlled trials with the Jadad scale $^{19}$ (Appendix 1, available at www.cmaj .ca/cgi/content/full/cmaj.092129/DC1). We conducted subgroup analyses according to methodologic quality (low-quality studies v. high-quality studies). For the observational studies, low quality was defined as Newcastle-Ottawa Scale score $\leq 8.0$ and high quality as score $>8.0$ (maximum score 9). For the randomized controlled trials, low quality was defined as Jadad scale score $\leq 3.0$ and high quality as score $>3.0$ (maximum score 5).

\section{Statistical analysis}

We computed a pooled OR and 95\% CI from the adjusted ORs and 95\% CIs reported in the observational studies. For randomized controlled trials, we computed the summary relative risk from the relative risks of the individual trials using Mantel-Haenszel weighting.

We examined heterogeneity in results across the studies using Higgins $I^{2}$ value, which measures the percentage of total variance in the summary estimate due to between-study heterogeneity. ${ }^{20}$

In light of the heterogeneity of study designs and population characteristics, we calculated the summary effect by means of the DerSimonianLaird method ${ }^{21}$ for random-effects models.

\section{Results}

We identified a total of 2377 articles in the initial search for observational studies, and we reviewed 60 abstracts and 18 full articles. We included 8 of these articles in our analysis. We identified 8513 randomized controlled trials, and we reviewed 914 abstracts and 35 full articles. We included 23 of these articles and 2 bibliographies of relevant articles in the study. In summary, we included five case-control studies, ${ }^{6,714,22,23}$ three cohort studies, ${ }^{2,10,24}$ and 23 
randomized controlled trials $s^{25-47}$ in the final analysis (Figure 1).

Table 1 and Table 2 summarize the general characteristics of the 31 studies that were included in the analysis. $2,6,7,10,14,22-47$ The mean quality scores were 8.4 for the observational studies (maximum score 9) and 3.1 for the randomized controlled trials (maximum score 5).

\section{Description of studies}

The selected studies were published between 1985 and 2009. Five articles reported population-based studies,,$^{2,67,14,23}$ and 26 articles, including the 23 randomized controlled trials, reported hospital-based studies..$^{10,22,24-47}$ Of the observational studies, five evaluated the association between use of acid-suppressive drugs
A

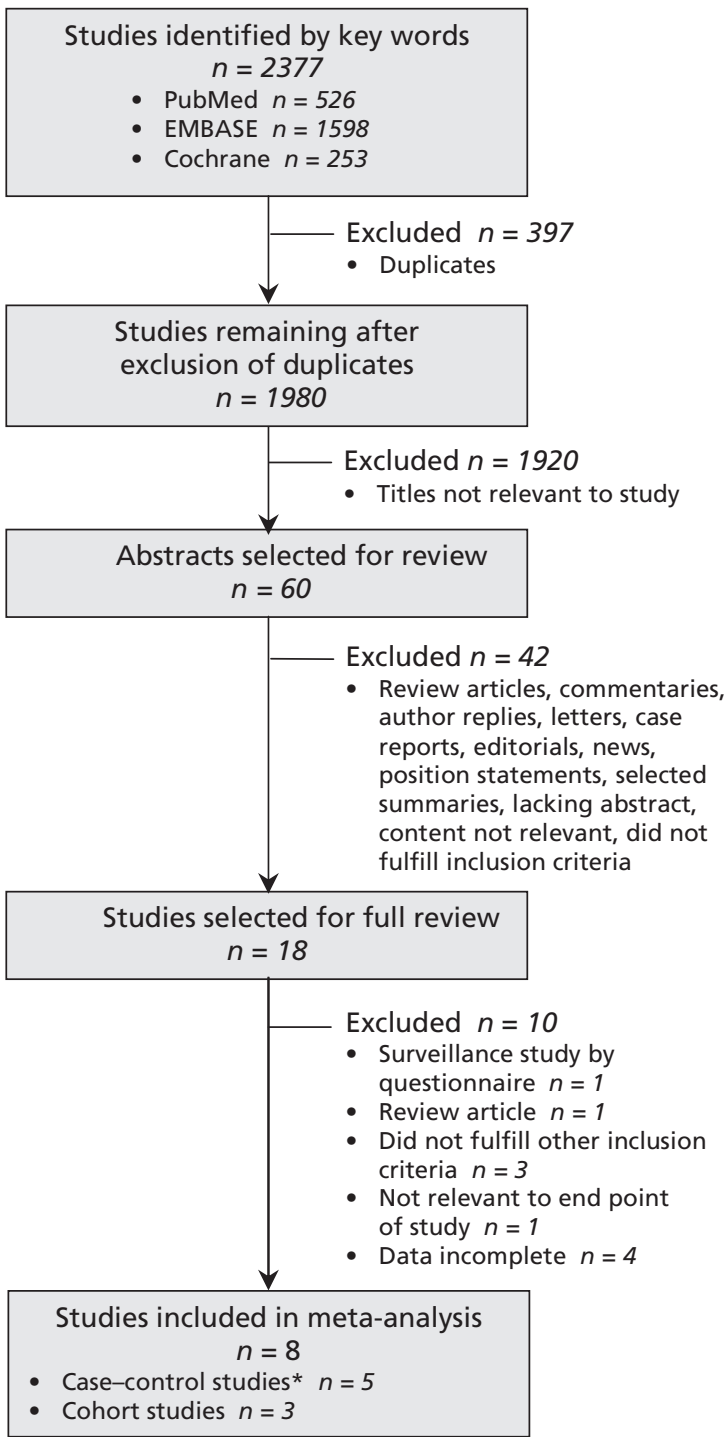

B

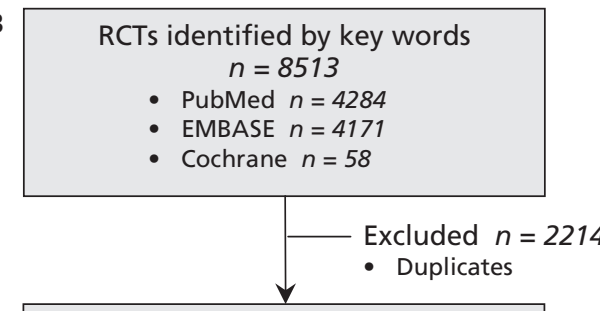

RCTs remaining after exclusion of duplicates $n=6299$

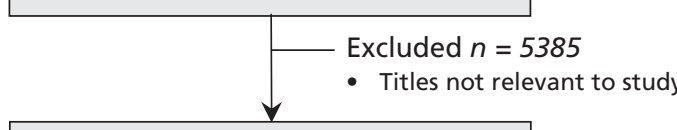

Abstracts selected for review $n=914$

Excluded $n=879$

- Not an RCT $n=70$

- Lacking abstract $n=86$

- Did not fulfill inclusion criteria $n=687$

- Did not include acid-suppressive drugs as intervention $n=16$

- Compared different dosages or durations of the same acidsuppressive drug $n=107$

- Compared two-drug regimens $n=59$

- Compared PPI with HRA $n=56$

- Compared acid-suppressive drug with drug other than placebo or sucralfate $n=48$

- No data about risk of pneumonia $n=401$

- Not relevant to end point of study $n=36$

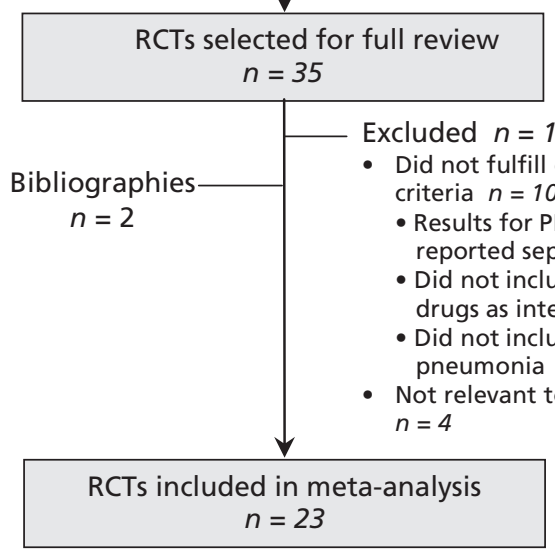

Figure 1: Selection of observational (case-control and cohort) studies (A) and randomized controlled trials (B) evaluating the risk of pneumonia in association with use of acid-suppressive drugs. *Includes nested case-control studies. $\mathrm{H}_{2} \mathrm{RA}=\mathrm{histamine}_{2}$ receptor antag onist, $\mathrm{PPI}=$ proton pump inhibitor, $\mathrm{RCT}=$ randomized controlled trial. 


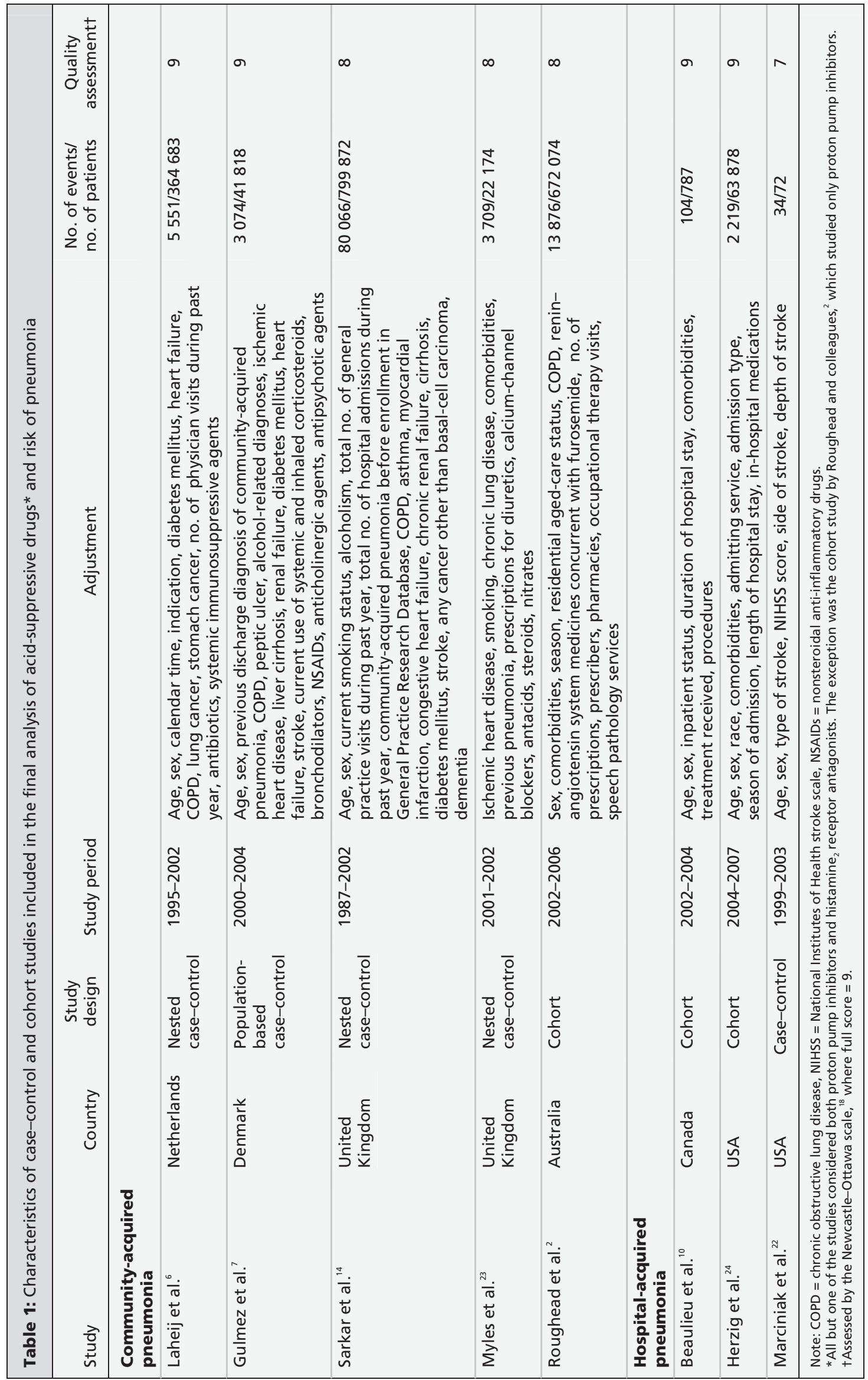


and risk of community-acquired pneumonia, ${ }^{2,67,14,23}$ and three evaluated the association between use of these drugs and risk of hospitalacquired pneumonia..$^{10,22,24}$

Main pooled analyses and heterogeneity Meta-analyses for observational studies with the two types of acid-suppressive drug showed sig- nificant positive associations between use of proton pump inhibitors and risk of pneumonia (adjusted OR 1.27, 95\% CI 1.11-1.46, I 90.5\%)

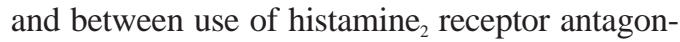
ists and risk of pneumonia (adjusted OR 1.22, 95\% CI 1.09-1.36, $I^{2} 0.0 \%$ ) (Figure 2).

Meta-analysis of the randomized controlled trials examining risk of hospital-acquired pneu-

\begin{tabular}{|c|c|c|c|c|c|c|}
\hline Study & Country & Study design & Study agent v. comparator & $\begin{array}{l}\text { No. of } \\
\text { patients }\end{array}$ & Study setting & $\begin{array}{c}\text { Quality } \\
\text { assessment* }\end{array}$ \\
\hline Cheadle et al. $^{25}$ & USA & Prospective RCT & Cimetidine v. placebo & 200 & Surgical unit & 5 \\
\hline Driks et al. ${ }^{26}$ & USA & Prospective RCT & $\mathrm{H}_{2} \mathrm{RAs}$, antacid v. sucralfate & 130 & $\begin{array}{l}\text { Surgical, } \\
\text { medical or } \\
\text { coronary ICU }\end{array}$ & 2 \\
\hline Laggner et al. ${ }^{27}$ & Austria & $\mathrm{RCT}$ & Ranitidine v. sucralfate & 32 & $\mathrm{ICU}$ & 2 \\
\hline Reusser et al. ${ }^{28}$ & Switzerland & Prospective RCT & Ranitidine v. placebo & 40 & $\begin{array}{l}\text { Neurosurgical } \\
\text { ICU }\end{array}$ & 2 \\
\hline Eddleston et al. ${ }^{29}$ & $\begin{array}{l}\text { United } \\
\text { Kingdom }\end{array}$ & Prospective RCT & Ranitidine v. sucralfate & 60 & ICU & 3 \\
\hline Apte et al. ${ }^{30}$ & India & Prospective RCT & Ranitidine v. placebo & 34 & Medical ICU & 2 \\
\hline Martin et al. ${ }^{31}$ & USA & $\begin{array}{l}\text { Multicentre double- } \\
\text { blinded RCT }\end{array}$ & Cimetidine v. placebo & $131+$ & ICU & 4 \\
\hline Metz et al. ${ }^{32}$ & USA & $\begin{array}{l}\text { Prospective, multicentre, } \\
\text { double-blind RCT }\end{array}$ & Ranitidine v. placebo & $167+$ & ICU & 5 \\
\hline Pickworth et al. ${ }^{33}$ & USA & Prospective RCT & Ranitidine v. sucralfate & 83 & Trauma centre & 3 \\
\hline Ryan et al..$^{34}$ & USA & Prospective RCT & Cimetidine v. sucralfate & 114 & $\begin{array}{l}\text { Medicosurgical } \\
\text { ICU }\end{array}$ & 3 \\
\hline $\begin{array}{l}\text { Ben-Menachem } \\
\text { et al. } .^{35}\end{array}$ & USA & Single-blind RCT & Cimetidine v. placebo & 200 & Medical ICU & 2 \\
\hline Cloud et al. ${ }^{36}$ & USA & $\begin{array}{l}\text { Multicentre parallel } \\
\text { double-blinded RCT }\end{array}$ & Nizatidine v. placebo & $126+$ & ICU & 2 \\
\hline Maier et al. ${ }^{37}$ & USA & Prospective open RCT & Ranitidine v. sucralfate & 98 & Trauma ICU & 2 \\
\hline Prod'hom et al. ${ }^{38}$ & Switzerland & $\mathrm{RCT}$ & Ranitidine v. sucralfate & $244 \dagger$ & $\begin{array}{l}\text { Medicosurgical } \\
\text { ICU }\end{array}$ & 3 \\
\hline Mustafa et al. ${ }^{39}$ & Turkey & Prospective RCT & Ranitidine v. sucralfate & 31 & ICU & 2 \\
\hline Thomason et al. ${ }^{40}$ & USA & Prospective RCT & Ranitidine v. sucralfate & $242+$ & $\begin{array}{l}\text { Trauma, surgical } \\
\text { or neurosurgical } \\
\text { ICU }\end{array}$ & 3 \\
\hline Cook et al. ${ }^{41}$ & Canada & Multicentre, blinded, RCT & Ranitidine v. placebo & 1200 & ICU & 5 \\
\hline Hanisch et al. ${ }^{42}$ & Germany & Double-blind RCT & Ranitidine v. placebo & $158+$ & ICU & 4 \\
\hline $\begin{array}{l}\text { Moesgaard } \\
\text { et al. }\end{array}$ & Denmark & Double-blind RCT & Ranitidine v. placebo & $194+$ & Surgical unit & 4 \\
\hline O'Keefe et al. ${ }^{44}$ & USA & Prospective RCT & Ranitidine v. sucralfate & 96 & $\begin{array}{l}\text { Severely injured } \\
\text { patients }\end{array}$ & 2 \\
\hline Yildizdas et al. ${ }^{45}$ & Turkey & Prospective RCT & Ranitidine v. placebo & $160+$ & Pediatric ICU & 3 \\
\hline Kantorova et al. ${ }^{46}$ & $\begin{array}{l}\text { Czech } \\
\text { Republic }\end{array}$ & $\mathrm{RCT}$ & Famotidine v. placebo & $287 \dagger$ & ICU & 5 \\
\hline Misra et al. ${ }^{47}$ & India & $\mathrm{RCT}$ & Ranitidine v. placebo & $141+$ & $\begin{array}{l}\text { Patients with } \\
\text { intracerebral } \\
\text { hemorrhage }\end{array}$ & 4 \\
\hline \multicolumn{7}{|c|}{$\begin{array}{l}\text { Note: } \mathrm{H}_{2} \mathrm{RAs}=\text { histamine }_{2}-\text { receptor antagonists, } \mathrm{ICU}=\text { intensive care unit. } \\
{ }^{*} \text { Assessed by Jadad scale, }{ }^{19} \text { where full score }=5 \text {. } \\
\text { †Some patients or comparison arms in these studies were excluded from the current meta-analysis (see Appendix 2, available at } \\
\text { www.cmaj.ca/cgi/content/full/cmaj.092129/DC1). }\end{array}$} \\
\hline
\end{tabular}


monia in association with use of histamine receptor antagonists confirmed the findings of the observational studies (relative risk 1.22, 95\% CI 1.01-1.48, I 30.6\%) (Figure 3).

\section{Subgroup meta-analyses}

In subgroup analyses by type of pneumonia, we observed a significant positive association between use of proton pump inhibitors and community-acquired pneumonia (adjusted OR 1.34, 95\% CI 1.14-1.57, $I^{2}$ 93.6\%) and between use of histamine $_{2}$ receptor antagonists and hospitalacquired pneumonia (adjusted OR 1.24, 95\% CI 1.05-1.47, $I^{2} 0.0 \%$ ) (Table 3).

Subgroup analyses by dose indicated a doseresponse relationship. A higher dose of proton pump inhibitors was more strongly associated with pneumonia (adjusted OR 1.52, 95\% CI $\left.1.31-1.76, I^{2} 27.5 \%\right)$ than the usual dose (adjusted OR 1.37, 95\% CI 1.08-1.74, I 86.5).

Subgroup analyses by duration of exposure showed that the strength of the association between use of proton pump inhibitors and risk of pneumonia decreased with longer duration of therapy before the index date (date of diagnosis of pneumonia). There were significant positive associations between risk of pneumonia and use of proton pump inhibitors within 7 days before the index date (adjusted OR 3.95, 95\% CI 2.86$5.45, I^{2} 0.0 \%$ ), within 30 days before the index date (adjusted OR 1.61, 95\% CI 1.46-1.78, $I^{2}$ $30.6 \%$ ) and from 30 to 180 days before the index date (adjusted OR 1.36, 95\% CI 1.05$\left.1.78, I^{2} 84.3 \%\right)$. The risk of pneumonia was greater with the use of histamine ${ }_{2}$ receptor antagonists within 7 days before the index date (adjusted OR 5.21, 95\% CI 4.00-6.80, $I^{2}$ not available). The risk also appeared greater with the use of these drugs within 30 days before the index date (adjusted OR 1.49, 95\% CI 0.82$2.72, I^{2} 80.4 \%$ ) and from 30 to 180 days (adjusted OR 1.21, 95\% CI 0.94-1.56, $I^{2}$

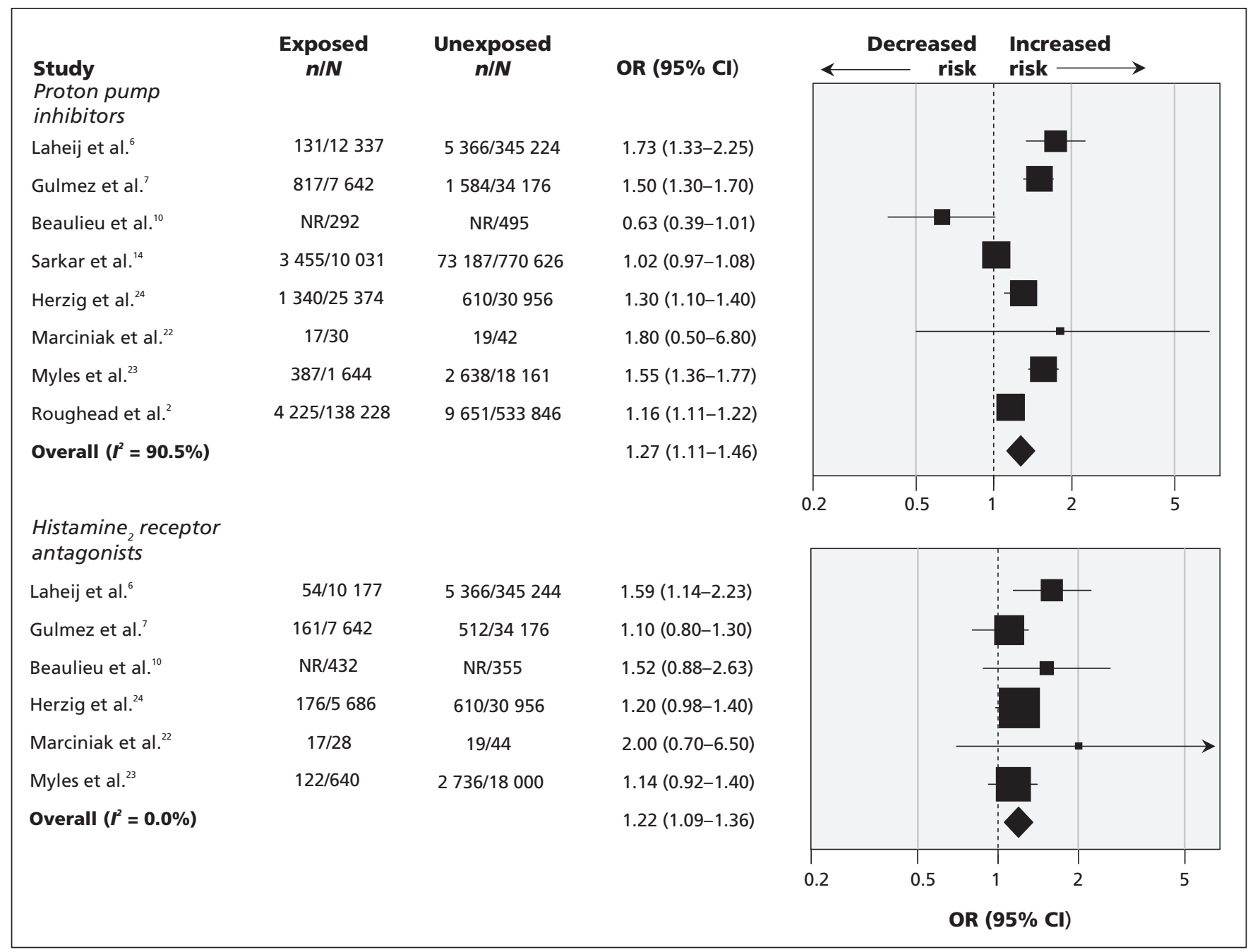

Figure 2: Meta-analyses of observational studies evaluating the risk of pneumonia among patients receiving acid-suppressive drugs, based on random-effects model. Adjusted odds ratios (ORs) greater than 1 indicate increased risk of pneumonia. $\mathrm{Cl}=\mathrm{confidence}$ interval, $P=$ heterogeneity, $n=$ number of events, $N=$ number of patients, NR = not reported. 
$27.6 \%$ ), but these associations were not statistically significant.

Subgroup analyses of the 23 randomized controlled trials by comparators showed a significant positive association between use of histamine ${ }_{2}$ receptor antagonists and risk of pneumonia in studies that employed sucralfate as a control (relative risk 1.33, 95\% CI 1.04-1.69, $I^{2} 24.7 \%$ ). Placebo-controlled studies also indicated an overall increase in the risk of pneumonia with these drugs, but the result was not statistically significant (relative risk 1.09, 95\% CI 0.80-1.48, $I^{2} 37.9 \%$ ).

We conducted subgroup meta-analyses of the observational studies and randomized controlled trials by methodologic quality. Among the observational studies, we observed a significant positive association for both high-quality studies (adjusted OR 1.29, 95\% CI 1.17-1.42, I $0.0 \%$ ) and low-quality studies (adjusted OR 1.15, 95\% CI 1.00-1.32, $I^{2} 82.1 \%$ ). Among the randomized controlled trials, the risk of pneumonia appeared greater in low-quality studies (relative risk 1.35, 95\% CI 1.10-1.67, $I^{2} 12.5 \%$ ), whereas there was no effect among the high-quality studies (relative risk $0.96,95 \%$ CI $0.65-1.43, I^{2} 47.0 \%$ ).

\section{Interpretation}

\section{Main findings}

Our results suggest that the use of acid-suppressive drugs is associated with an increased risk of pneumonia. Given the widespread use of acidsuppressive drugs, the implications of this increased risk are serious. If we assume that 19.7 cases of pneumonia occur for every 1000 individuals not receiving acid-suppressive drugs who are admitted to hospital, ${ }^{24}$ and if we also assume a 1.22 - to 1.27 -fold increase in the risk of pneumonia due to acid-suppressive drugs, as determined in this study, 24 or 25 cases of pneumonia can be expected for every 1000 recipients of these drugs. This translates to about one case of pneumonia for every 200 inpatients treated with acidsuppressive drugs. Given that $40 \%-70 \%$ of patients admitted to hospital receive acid-suppressive drugs ${ }^{48}$ a considerable burden of morbidity and mortality of hospital-acquired pneumonia may be attributable to this type of therapy. In the context of community-acquired pneumonia, the impact of these drugs could be even more serious.

Several lines of evidence point to the bio-

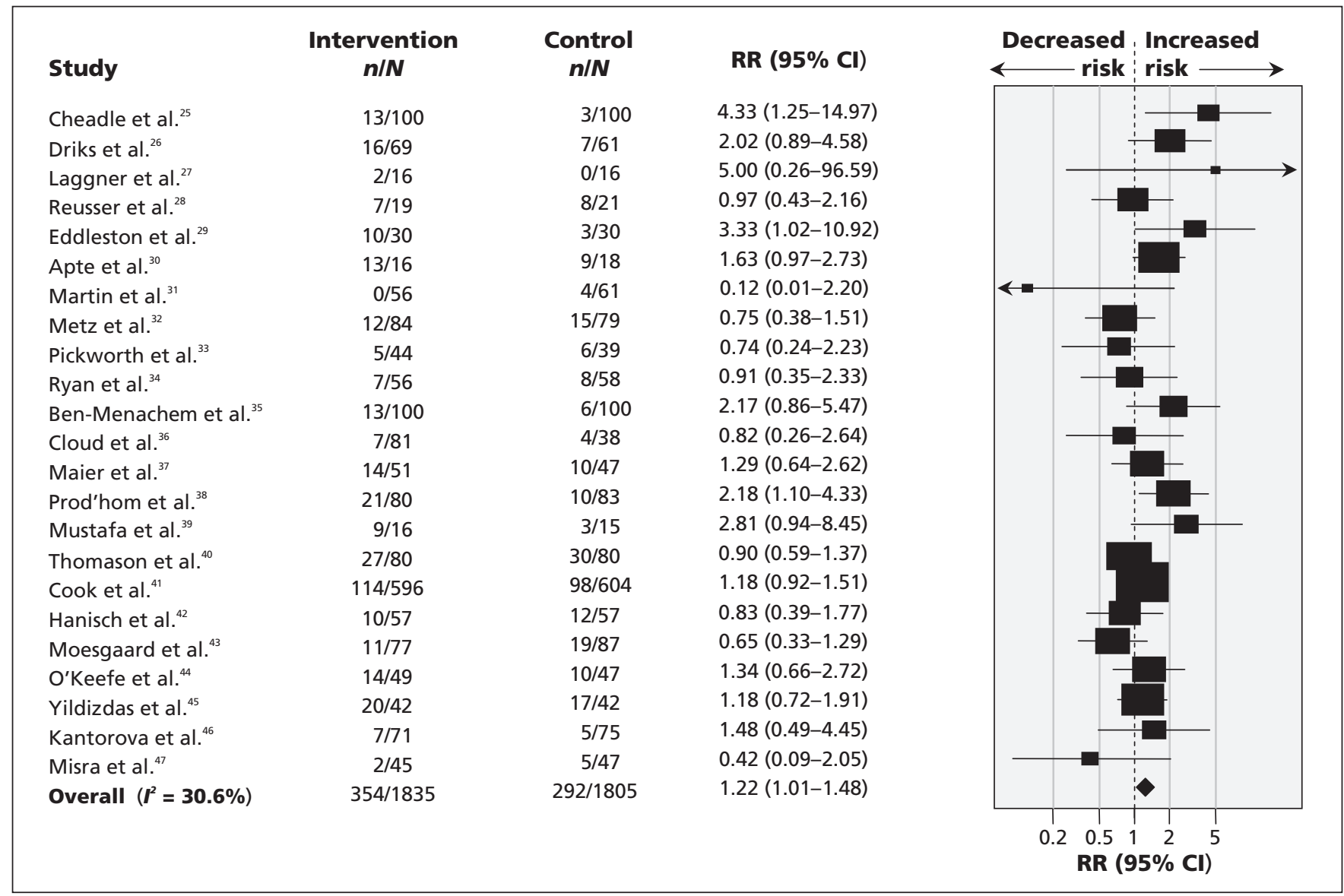

Figure 3: Meta-analysis of randomized controlled trials evaluating the risk of hospital-acquired pneumonia among patients using histamine $_{2}$ receptor antagonists, based on random-effects model. Relative risk (RR) values greater than 1 indicate increased risk of pneumonia. $\mathrm{Cl}=$ confidence interval, $P=$ heterogeneity, $n=$ number of events, $N=$ number of patients. 
logical plausibility of these observations. First, acid-suppressive drugs may increase the risk of pneumonia by inhibiting the secretion of gastric acid, thus allowing bacterial overgrowth and colonization in the upper alimentary tract and subsequent translocation to the lungs by aspiration. . $^{6,49}$ Second, hydrogen potassium adenosine triphosphatase is present not only in the parietal cells of the stomach, but also in the respiratory tract. ${ }^{50,51}$ It is conceivable that use of a proton pump inhibitor could alter the $\mathrm{pH}$ of the seromucinous secretions by inhibiting this enzyme, thereby encouraging bacterial growth in the respiratory tract, which could in turn lead to increased risk of pneumonia. ${ }^{52}$ Third, in vitro studies have shown that acid-suppressive drugs may impair the function of neutrophils and the activity of natural killer cells. ${ }^{53-59}$

Interestingly, the most striking increase in the risk of pneumonia in association with proton pump inhibitors was observed in the first week of use. The risk of pneumonia in association with use of proton pump inhibitors was attenuated, but still significant, between 30 and 180 days. Recipients of histamine ${ }_{2}$ receptor antagonists between 30 and 180 days before the index date appeared to have an increased risk of pneumonia, but the association was not statistically significant. These findings might reflect tolerance. ${ }^{52}$ Tolerance to histamine receptor antagonists generally develops within two weeks with repeated administration, resulting in a decline in acid suppression. ${ }^{60}$ Another reason may be that those who are more susceptible to pneumonia become ill with this disease early after starting acid-suppressive drugs, leaving fewer such individuals among those using these drugs for longer periods. That is, patients who remain on the drug are those who can tolerate it, whereas those who are susceptible select themselves out of the population at risk. This depletion of susceptible effect has been considered in other pharmacoepidemiologic studies of adverse events. ${ }^{61}$

\section{Comparisons with other studies}

Previous meta-analyses ${ }^{11,13,15}$ examined the effect of acid-suppressive drugs on pneumonia as a secondary outcome in randomized controlled trials. Cook and associates ${ }^{11}$ showed that the rate of pneumonia was higher among patients taking histamine $_{2}$ receptor antagonists than among controls, but the difference was not statistically significant (OR 1.25, 95\% CI 0.78-2.00). Conversely, Messori and colleagues ${ }^{13}$ found no difference in the risk of pneumonia between those who were given ranitidine and those who were given placebo (OR 0.98 , 95\% CI $0.56-$ 1.72). However, they found an increased risk of nosocomial pneumonia in studies comparing ranitidine and sucralfate (OR 2.21, 95\% CI 0.865.65). Finally, Pongprasobchai and coworkers ${ }^{15}$ reported that the incidence of nosocomial pneumonia did not differ between patients receiving proton pump inhibitors and those receiving histamine $_{2}$ receptor antagonists. Compared with the previous meta-analyses, our review included more studies, which led to greater power to detect an effect. We also included observational studies, which enrolled a greater diversity of individuals, especially those taking high doses of acid-suppressive drugs.

Table 3: Subgroup analyses for use of acid-suppressive agents and risk of pneumonia using random-effects model for observational studies

\begin{tabular}{|c|c|c|c|}
\hline Factor & $\begin{array}{l}\text { No. of } \\
\text { studies }\end{array}$ & $\begin{array}{c}\text { Summary adjusted OR } \\
(95 \% \mathrm{Cl})\end{array}$ & $I^{2}, \%$ \\
\hline \multicolumn{4}{|l|}{ Proton pump inhibitors } \\
\hline \multicolumn{4}{|l|}{ Study design } \\
\hline $\begin{array}{l}\text { Case-control and nested } \\
\text { case-control }\end{array}$ & 5 & $1.44(1.09-1.91)$ & 93.7 \\
\hline Cohort & 3 & $1.14(0.96-1.36)$ & 79.1 \\
\hline \multicolumn{4}{|l|}{ Study population } \\
\hline General & 5 & $1.34(1.14-1.57)$ & 93.6 \\
\hline Hospital & 3 & $1.04(0.58-1.88)$ & 76.9 \\
\hline \multicolumn{4}{|l|}{ Type of pneumonia } \\
\hline Community-acquired & 5 & $1.34(1.14-1.57)$ & 93.6 \\
\hline Hospital-acquired & 3 & $1.04(0.58-1.88)$ & 76.9 \\
\hline \multicolumn{4}{|l|}{ Dose } \\
\hline Usual & 3 & 1.37 (1.08-1.74) & 86.5 \\
\hline High & 3 & $1.52(1.31-1.76)$ & 27.5 \\
\hline \multicolumn{4}{|l|}{ Duration of exposure, $d$} \\
\hline$<7$ & 2 & $3.95(2.86-5.45)$ & 0.0 \\
\hline$<30$ & 4 & $1.61(1.46-1.78)$ & 30.6 \\
\hline $30-180$ & 4 & $1.36(1.05-1.78)$ & 84.3 \\
\hline \multicolumn{4}{|l|}{$\begin{array}{l}\text { Histamine }{ }_{2} \text { receptor } \\
\text { antagonists }\end{array}$} \\
\hline \multicolumn{4}{|l|}{ Study design } \\
\hline $\begin{array}{l}\text { Case-control and } \\
\text { nested case-control }\end{array}$ & 4 & $1.20(1.01-1.43)$ & 15.5 \\
\hline Cohort study & 2 & $1.23(1.04-1.45)$ & 0.0 \\
\hline \multicolumn{4}{|l|}{ Study population } \\
\hline General & 3 & $1.19(0.99-1.42)$ & 25.7 \\
\hline Hospital & 3 & $1.24(1.05-1.47)$ & 0.0 \\
\hline \multicolumn{4}{|l|}{ Type of pneumonia } \\
\hline Community-acquired & 3 & $1.19(0.99-1.42)$ & 25.7 \\
\hline Hospital-acquired & 3 & $1.24(1.05-1.47)$ & 0.0 \\
\hline \multicolumn{4}{|l|}{ Duration of exposure, $d$} \\
\hline$<7$ & 1 & $5.21(4.00-6.80)$ & NR \\
\hline$<30$ & 2 & $1.49(0.82-2.72)$ & 80.4 \\
\hline $30-180$ & 2 & $1.21(0.94-1.56)$ & 27.6 \\
\hline
\end{tabular}




\section{Strengths and limitations}

Our analysis incorporated all relevant studies that we could identify to August 2009, including both observational and randomized controlled trials. We were also able to identify sources of heterogeneity by stratifying analyses on key variables.

Despite these strengths, our study had some limitations. First, we included only Englishlanguage publications for the selection of observational studies. We performed a subsequent search for all relevant observational studies without any language restrictions and found about $18 \%$ more citations. However, none of these articles met the inclusion criteria. It is unlikely that the language of the studies would have altered the validity or magnitude of the associations between acid-suppressive drugs and pneumonia. Second, the presence of gastroesophageal reflux disease might be a confounder, ${ }^{49}$ as those who receive acid-suppressive drugs often experience this condition, which in itself could be a risk factor for pneumonia. However, given that the included studies adjusted for factors such as comorbidities and other medications, any resulting bias was unlikely to have been great enough to explain the observed effect. Third, although the high-quality observational studies showed a significant effect, the high-quality doubleblinded randomized controlled trials did not show a significant effect. This discrepancy might be attributable to methodologic rigour, but differences in study characteristics may also have contributed to the heterogeneous results.

\section{Conclusion}

Clinicians should carefully consider any decision to prescribe acid-suppressive drugs, especially for patients who are already at risk for pneumonia. ${ }^{62}$ Since it is unnecessary to achieve an achlorhydric state in order to resolve symptoms, we recommend using the optimal effective dose of the drug necessary to achieve desired therapeutic goals.

\section{References}

1. Community-acquired pneumonia and acid-suppressive drugs: position statement. Can J Gastroenterol 2006;20:119-21, 123-5.

2. Roughead EE, Ramsay EN, Pratt NL, et al. Proton-pump inhibitors and the risk of antibiotic use and hospitalisation for pneumonia. Med J Aust 2009;190:114-6.

3. Gregor JC. Acid suppression and pneumonia: a clinical indication for rational prescribing. JAMA 2004;292:2012-3.

4. Vanderhoff BT, Tahboub RM. Proton pump inhibitors: an update. Am Fam Physician 2002;66:273-80.

5. Laine L, Ahnen D, McClain C, et al. Review article: potential gastrointestinal effects of long-term acid suppression with proton pump inhibitors. Aliment Pharmacol Ther 2000;14:651-68.

6. Laheij RJ, Sturkenboom MC, Hassing RJ, et al. Risk of community-acquired pneumonia and use of gastric acid-suppressive drugs. JAMA 2004;292:1955-60.

7. Gulmez SE, Holm A, Frederiksen H, et al. Use of proton pump inhibitors and the risk of community-acquired pneumonia: a population-based case-control study. Arch Intern Med 2007; 167:950-5.

8. Laheij RJ, Van Ijzendoorn MC, Janssen MJ, et al. Gastric acidsuppressive therapy and community-acquired respiratory infections. Aliment Pharmacol Ther 2003;18:847-51.

9. Canani RB, Cirillo P, Roggero P, et al. Therapy with gastric acidity inhibitors increases the risk of acute gastroenteritis and community-acquired pneumonia in children. Pediatrics 2006; 117:e817-20.

10. Beaulieu M, Williamson D, Sirois C, et al. Do proton-pump inhibitors increase the risk for nosocomial pneumonia in a medical intensive care unit? J Crit Care 2008;23:513-8.

11. Cook DJ, Reeve BK, Guyatt GH, et al. Stress ulcer prophylaxis in critically ill patients. Resolving discordant meta-analyses. JAMA 1996;275:308-14.

12. Estborn L, Joelson S. Occurrence of community-acquired respiratory tract infection in patients receiving esomeprazole: retrospective analysis of adverse events in 31 clinical trials. Drug Saf 2008;31:627-36

13. Messori A, Trippoli S, Vaiani M, et al. Bleeding and pneumonia in intensive care patients given ranitidine and sucralfate for prevention of stress ulcer: meta-analysis of randomised controlled trials. BMJ 2000;321:1103-6.

14. Sarkar M, Hennessy S, Yang YX. Proton-pump inhibitor use and the risk for community-acquired pneumonia. Ann Intern Med 2008;149:391-8.

15. Pongprasobchai S, Kridkratoke S, Nopmaneejumruslers C. Proton pump inhibitors for the prevention of stress-related mucosal disease in critically-ill patients: a meta-analysis. J Med Assoc Thai 2009;92:632-7.

16. Stroup DF, Berlin JA, Morton SC, et al. Meta-analysis of observational studies in epidemiology: a proposal for reporting. Metaanalysis Of Observational Studies in Epidemiology (MOOSE) group. JAMA 2000;283:2008-12.

17. Liberati A, Altman DG, Tetzlaff J, et al. The PRISMA statement for reporting systematic reviews and meta-analyses of studies that evaluate health care interventions: explanation and elaboration. J Clin Epidemiol 2009;62:e1-34.

18. Wells G, Shea B, O'Connell D, et al. The Newcastle-Ottawa Scale (NOS) for assessing the quality of nonrandomised studies in meta-analyses. Ottawa (ON): Ottawa Hospital Research Institute; 2009. Available: www.ohri.ca/programs/clinical_epidemiology /oxford.asp (accessed 2010 Aug.).

19. Jadad AR, Moore RA, Carroll D, et al. Assessing the quality of reports of randomized clinical trials: Is blinding necessary? Control Clin Trials 1996;17:1-12.

20. Higgins JP, Thompson SG, Deeks JJ, et al. Measuring inconsistency in meta-analyses. BMJ 2003;327:557-60.

21. DerSimonian R, Laird N. Meta-analysis in clinical trials. Control Clin Trials 1986;7:177-88.

22. Marciniak C, Korutz AW, Lin E, et al. Examination of selected clinical factors and medication use as risk factors for pneumonia during stroke rehabilitation: a case-control study. Am J Phys Med Rehabil 2009;88:30-8

23. Myles PR, Hubbard RB, McKeever TM, et al. Risk of communityacquired pneumonia and the use of statins, ACE inhibitors and gastric acid suppressants: a population-based case-control study. Pharmacoepidemiol Drug Saf 2009;18:269-75.

24. Herzig SJ, Howell MD, Ngo LH, et al. Acid-suppressive medication use and the risk for hospital-acquired pneumonia. JAMA 2009;301:2120-8.

25. Cheadle WG, Vitale GC, Mackie CR, et al. Prophylactic postoperative nasogastric decompression. A prospective study of its requirement and the influence of cimetidine in 200 patients. Ann Surg 1985;202:361-6.

26. Driks MR, Craven DE, Celli BR, et al. Nosocomial pneumonia in intubated patients given sucralfate as compared with antacids or histamine type 2 blockers. The role of gastric colonization. $N$ Engl J Med 1987;317:1376-82.

27. Laggner AN, Lenz K, Base W, et al. Prevention of upper gastrointestinal bleeding in long-term ventilated patients. Sucralfate versus ranitidine. Am J Med 1989;86:81-4.

28. Reusser P, Zimmerli W, Scheidegger D, et al. Role of gastric colonization in nosocomial infections and endotoxemia: a prospective study in neurosurgical patients on mechanical ventilation. J Infect Dis 1989;160:414-21.

29. Eddleston JM, Vohra A, Scott P, et al. A comparison of the frequency of stress ulceration and secondary pneumonia in sucralfate- or ranitidine-treated intensive care unit patients. Crit Care Med 1991;19:1491-6.

30. Apte NM, Karnad DR, Medhekar TP, et al. Gastric colonization and pneumonia in intubated critically ill patients receiving stress ulcer prophylaxis: a randomized, controlled trial. Crit Care Med 1992;20:590-3. 
31. Martin LF, Booth FV, Karlstadt RG, et al. Continuous intravenous cimetidine decreases stress-related upper gastrointestinal hemorrhage without promoting pneumonia. Crit Care Med 1993;21:19-30.

32. Metz CA, Livingston DH, Smith JS, et al. Impact of multiple risk factors and ranitidine prophylaxis on the development of stress-related upper gastrointestinal bleeding: a prospective, multicenter, double-blind, randomized trial. The Ranitidine Head Injury Study Group. Crit Care Med 1993;21:1844-9.

33. Pickworth KK, Falcone RE, Hoogeboom JE, et al. Occurrence of nosocomial pneumonia in mechanically ventilated trauma patients: a comparison of sucralfate and ranitidine. Crit Care Med 1993;21:1856-62.

34. Ryan P, Dawson J, Teres D, et al. Nosocomial pneumonia during stress ulcer prophylaxis with cimetidine and sucralfate. Arch Surg 1993;128:1353-8.

35. Ben-Menachem T, Fogel R, Patel RV, et al. Prophylaxis for stress-related gastric hemorrhage in the medical intensive care unit. A randomized, controlled, single-blind study. Ann Intern Med 1994;121:568-75

36. Cloud ML, Offen W. Continuous infusions of nizatidine are safe and effective in the treatment of intensive care unit patients at risk for stress gastritis. The Nizatidine Intensive Care Unit Study Group. Scand J Gastroenterol Suppl 1994;206:29-34.

37. Maier RV, Mitchell D, Gentilello L. Optional therapy for stress gastritis. Ann Surg 1994;220:353-60.

38. Prod'hom G, Leuenberger P, Koerfer J, et al. Nosocomial pneumonia in mechanically ventilated patients receiving antacid, ranitidine, or sucralfate as prophylaxis for stress ulcer. A randomized controlled trial. Ann Intern Med 1994;120:653-62.

39. Mustafa NA, Akturk G, Ozen I, et al. Acute stress bleeding prophylaxis with sucralfate versus ranitidine and incidence of secondary pneumonia in intensive care unit patients. Intensive Care Med 1995;21:287

40. Thomason MH, Payseur ES, Hakenewerth AM, et al. Nosocomial pneumonia in ventilated trauma patients during stress ulcer prophylaxis with sucralfate, antacid, and ranitidine. J Trauma 1996;41:503-8.

41. Cook D, Guyatt G, Marshall J, et al. A comparison of sucralfate and ranitidine for the prevention of upper gastrointestinal bleeding in patients requiring mechanical ventilation. Canadian Critical Care Trials Group. N Engl J Med 1998;338:791-7.

42. Hanisch EW, Encke A, Naujoks F, et al. A randomized, doubleblind trial for stress ulcer prophylaxis shows no evidence of increased pneumonia. Am J Surg 1998;176:453-7.

43. Moesgaard F, Jensen LS, Christiansen PM, et al. The effect of ranitidine on postoperative infectious complications following emergency colorectal surgery: a randomized, placebocontrolled, double-blind trial. Inflamm Res 1998;47:12-7.

44. O'Keefe GE, Gentilello LM, Maier RV. Incidence of infectious complications associated with the use of histamine ${ }_{2}$-receptor antagonists in critically ill trauma patients. Ann Surg 1998;227:120-5.

45. Yildizdas D, Yapicioglu H, Yilmaz HL. Occurrence of ventilatorassociated pneumonia in mechanically ventilated pediatric intensive care patients during stress ulcer prophylaxis with sucralfate, ranitidine, and omeprazole. J Crit Care 2002;17:240-5.

46. Kantorova I, Svoboda P, Scheer P, et al. Stress ulcer prophylaxis in critically ill patients: a randomized controlled trial. Hepatogastroenterology 2004;51:757-61.

47. Misra UK, Kalita J, Pandey S, et al. A randomized placebo controlled trial of ranitidine versus sucralfate in patients with spontaneous intracerebral hemorrhage for prevention of gastric hemorrhage. J Neurol Sci 2005;239:5-10.

48. Nardino RJ, Vender RJ, Herbert PN. Overuse of acid-suppressive theraphy in hospitalized patients. Am J Gastroenterol 2000; 95:3118-22.

49. Nealis TB, Howden CW. Is there a dark side to long-term proton pump inhibitor therapy? Am J Ther 2008;15:536-42.

50. Altman KW, Waltonen JD, Hammer ND, et al. Proton pump $\left(\mathrm{H}^{+} / \mathrm{K}^{+}\right.$-ATPase $)$expression in human laryngeal seromucinous glands. Otolaryngol Head Neck Surg 2005;133:718-24.
51. Altman KW, Waltonen JD, Tarjan G, et al. Human lung mucous glands manifest evidence of the $\mathrm{H}^{+} / \mathrm{K}^{+}$-ATPase proton pump. Ann Otol Rhinol Laryngol 2007;116:229-34

52. Savarino V, Di Mario F, Scarpignato C. Proton pump inhibitors in GORD. An overview of their pharmacology, efficacy and safety. Pharmacol Res 2009;59:135-53.

53. Aybay C, Imir T, Okur H. The effect of omeprazole on human natural killer cell activity. Gen Pharmacol 1995;26:1413-8.

54. Capodicasa E, De Bellis F, Pelli MA. Effect of lansoprazole on human leukocyte function. Immunopharmacol Immunotoxicol 1999;21:357-77.

55. Mikawa K, Akamatsu H, Nishina K, et al. The effects of cimetidine, ranitidine, and famotidine on human neutrophil functions. Anesth Analg 1999;89:218-24.

56. Scaringi L, Cornacchione P, Fettucciari K, et al. Activity inhibition of cytolytic lymphocytes by omeprazole. Scand J Immunol 1996;44:204-14.

57. Zedtwitz-Liebenstein K, Wenisch C, Patruta S, et al. Omeprazole treatment diminishes intra- and extracellular neutrophil reactive oxygen production and bactericidal activity. Crit Care Med 2002;30:1118-22.

58. Noble DW. Proton pump inhibitors and stress ulcer prophylaxis: Pause for thought? Crit Care Med 2002;30:1175-6.

59. Yoshida N, Yoshikawa T, Tanaka Y, et al. A new mechanism for anti-inflammatory actions of proton pump inhibitors-inhibitory effects on neutrophil-endothelial cell interactions. Aliment Pharmacol Ther 2000;14(Suppl 1):74-81.

60. Wilder-Smith $\mathrm{CH}$, Merki HS. Tolerance during dosing with $\mathrm{H}_{2-}$ receptor antagonists. An overview. Scand J Gastroenterol Suppl 1992;193:14-9.

61. Yola M, Lucien A. Evidence of the depeletion of susceptible effect in non-experimental pharmacoepidemiologic research. $J$ Clin Epidemiol 1994;47:731-7.

62. Brandt D. Acid suppression and pneumonia. Am J Nurs 2005; 105:21.

Affiliations: From the Department of Family Medicine (Eom, Lim, Cho, Park), Seoul National University Hospital, Seoul, Republic of Korea; Seoul National University College of Medicine (Park), Seoul, Republic of Korea; the Department of Epidemiology (Jeon), Harvard School of Public Health, Boston, Mass.; and the Department of Preventive Medicine (Lee), College of Medicine, The Catholic University of Korea, Seoul, Republic of Korea

Contributors: As the primary author, Chun-Sick Eom was responsible for the initial research plan; design of the study; collection, extraction and interpretation of the data; drafting of the manuscript; and statistical analysis. Christie Y. Jeon provided insight into the statistical methods and participated in drafting and critical revision of the manuscript for important intellectual content. Ju-Won Lim and Eun-Geol Cho were responsible for collection and extraction of the data and critical revision of the manuscript. Sang Min Park and KangSook Lee were responsible for interpretation of the data, drafting of the manuscript and critical revision of the manuscript for important intellectual content, as well as contributing equally as co-corresponding authors. All authors read and approved the manuscript submitted for publication. This paper's contents are solely the responsibility of the authors. Chun-Sick Eom is the guarantor for this paper and has full responsibility for this study.

Funding: This research was supported by the Basic Science Research Program of the National Research Foundation of Korea (grant 2010-0004429), which is funded by the Ministry of Education, Science, and Technology of the Korean government. 